\title{
Anatomical Characteristics of Sunlight-induced Bark (Periderm) Coverages on Columnar Cacti of Central Mexico
}

\author{
Lance S. Evans ${ }^{1} \&$ Phillip Dombrovskiy ${ }^{1}$ \\ ${ }^{1}$ Laboratory of Plant Morphogenesis, Manhattan College, the Bronx, NY 10471, USA \\ Correspondence: Lance S. Evans, New York Botanical Garden, the Bronx 10458, USA. Tel: 011-914-366-0812. \\ E-mail: lance.evans366@gmail.com
}

Received: April 26, 2020

doi:10.5539/jps.v9n2p20
Accepted: May 18, $2020 \quad$ Online Published: May 26, 2020

URL: https://doi.org/10.5539/jps.v9n2p20

\begin{abstract}
More than twenty-three species of tall, long-lived columnar cacti from a large variety of locations within the Americas show sunlight-induced periderm development on their stems. Periderm coverages lead to cactus morbidity and mortality. Our objective was to determine if periderm coverage patterns and anatomical characteristics of periderm formation differ among five cactus species located at a single site. Periderm coverages, patterns of periderm coverages and histological changes during the periderm formation process were determined for five native species of tall, long-lived columnar cacti in the Tehuacán Valley of Puebla, Mexico during May to June 2019. Periderm coverages and patterns of periderm on cactus surface varied among the species. On surfaces, some species had periderm form at crests initially, while one species had initial periderm form where troughs join. All species had the same internal tissues but the characteristics of these tissues varied among species. In response to periderm formation, one species retained its cuticle while one species retained its hypodermis intact and another produced cork cells inside the hypodermis. Overall, the histological changes that result from periderm formation were specific for each species and no pair of species showed the same responses to periderm formation. In conjunction with data from species from South America, eight distinct scenarios of histological manifestations were documented. Although, each of the five cactus species were in the same location and received the same amount of sunlight exposures, each species showed unique periderm coverages on surfaces, unique anatomical characteristics and unique anatomical responses. Thus, location was not the primary determinant of responses.
\end{abstract}

Keywords: bark (periderm) development, cactus surface characteristics, cactus anatomy

\section{Introduction}

More than twenty-three species of tall, long-lived columnar cacti from a large variety of locations within the Americas show sunlight-induced periderm coverages on their stems (Evans et al., 2003; 2015). Sunlight-induced periderm formation is directional. Sunlight-induced proliferation of epidermal cells begins on equatorial-facing surfaces (Evans \& Macri, 2008). For species in the Northern Hemisphere, periderm coverages begins on south-facing surfaces and eventually occurs on north-facing surfaces (Evans et al., 1994a). In contrast, columnar cactus species in the Southern Hemisphere start experiencing periderm coverage on north-facing surfaces before eventually coverages occur on south-facing surfaces (Evans et al., 1994b).

Sunlight induced periderm coverages lead to cactus morbidity and mortality for saguaro cacti (Carnegiea gigantea; Evans et al., 2013; Evans \& De Bonis, 2015). For a population of 1149 cacti first evaluated in 1993/4, more than 500 of these cacti that where showing extensive periderm coverages died by 2017. For this population, there was a $100 \%$ probably of cactus death within an eight-year period after north-facing right troughs had more than $85 \%$ periderm coverages (Evans \& Johnson, 2018; Evans et al., 2019).

On cactus plants, periderm is formed by the proliferation of epidermal cells (Evans et al., 1994). After many new epidermal cells are produced, the epidermal cells accumulate cellular constituents to form a protective layer underlying cells (Evans et al., 1994). The process of periderm formation may not be the same for all cactus species. However, the strong directional characteristic of the cacti in this study and in previous studies indicate that sunlight is the main contributor to periderm formation for plants of this study.

Dermal tissues of cactus plants involve a cuticle, an epidermis and a hypodermis (Rizzardini, 1984; Gibson \& 
Nobel, 1986; Darling, 1989; Evans et al., 1994a, b; Terrazas \& Aries, 2002). Usually, the epidermis is one-celled (Soffiatti \& Angyalossy, 2007; Garcia et al., 2012) while the hypodermis may contain of up to ten cell layers (Gibson \& Horak, 1978; Rizzardini, 1984; Gibson \& Nobel, 1986; Darling, 1989; Evans et al., 1994a,b; Loza-Cornejo \& Terrazas, 1996; Mauseth \& Keisling, 1997; Ginocchio \& Montenegro, 2000; Terrazas \& Aries, 2002; Mauseth, 2006). Several publications have shown the variety of dermal characteristics among cactus species (Loza-Cornejo \& Terrazas, 2003; Evans \& Cooney, 2015.

Gibson \& Nobel (1986) demonstrated that the phellogen (bark cambium) is created only by periclinal cell divisions by epidermal cells in Ferocactus robustrus. However, recent evidence indicated that some cactus species have anticlinal cell divisions of the epidermis to create the phellogen, this occurs before a large number of periclinal cell divisions which generate a multilayered periderm (Evans \& Cooney, 2015). There may be a variety of processes enacted in order to generate a periderm.

Although the process of creating a phellogen may vary among cactus species (Gibson \& Nobel, 1986; Evans \& Cooney, 2015), the cactus species that have been analyzed are located in a wide variety of locations. Few species of tall, long-lived cactus species occur in one location. Are the variety of processes which create a phellogen determined by location? The current study aims to document periderm development for five cactus species in one location. The current study documents the histological changes which occur during periderm coverage for five native species of tall, long-lived columnar cacti in the Tehuacán Valley of Puebla, Mexico. The overall hypothesis of this study is that periderm coverage patterns and anatomical characteristics of periderm formation will differ among cactus species. This study will:

Document the percentages of sunlight-induced periderm coverages on cactus stems.

Document stem surface characteristics of five species with and without periderm.

Document anatomical characteristics of five species with and without periderm.

Document the above characteristics for cacti growing in one location.

\section{Materials and Methods}

\subsection{Site Characteristics and Species Studied}

Populations of Cephalocereus macrocephalus F.A.C.Weber ex K.Schum., Gesamtbeschr. Kakt. 197 (1897) (http://www.ipni.org - 10 April 2020). , C. mezcalaensis var. robustus E.Y.Dawson, Allan Hancock Found. Publ. Occas. Pap. no. 1: 9 (1948) (http://www.ipni.org - 10 April 2020), C. tetetzo Vaupel, Monatsschr. Kakteenk. xix. 73 (1909), in obs., nomen; Bravo in An. Inst.Biol. Mexico, 1930, i. 98. (http://www.ipni.org - 10 April 2020), and Pachycereus hollianus f. cristatus P.V.Heath, Calyx 2(3): 106 (1992) (http://www.ipni.org -10 April 2020) were studied from May to June of 2018 at the Tehuacán-Cuicatlán Biosphere Reserve (Smith, 1965; http://www.sanjuanraya.com), San Juan Raya, Puebla, Mexico $\left(18.10^{\circ} \mathrm{N}, 97.21^{\circ} \mathrm{W}\right)$. The Tehuacán-Cuicatlán Biosphere Reserve is a UNESCO site protected by local citizens in San Juan Raya (http://www.sanjuanraya.com). This area is considered a semi-arid zone (Valiente-Banuet \& Ezcurra, 1991; Davila et al., 2002; Altesor \& Ezcurra, 2003) with the richest cactus biodiversity in all of North America (UNESCO). A population of Cephalocereus columna-trajani (Karw.) K.Schum.) (http://www.ipni.org - 10 April 2020) was examined near Highway 125, Puebla, Mexico $\left(18.20^{\circ} \mathrm{N}, 97.30^{\circ} \mathrm{W}\right)$. Local personal confirmed the names of the species studied. The morphological descriptions followed the terminology of Anderson (2001). Valiente-Banuet \& Ezcurra (1991) studied this species of $C$. tetetzo in the Tehuacan Valley.

\subsection{Evaluation of Periderm Coverages}

Since the aim of the study was to examine sunlight-induced periderm formation, only cacti that were not shaded by surrounding plants were considered for evaluation. For cacti, the periderm refers to a secondary protective tissue that replaces the epidermis on stems and roots (Angyalossy et al., 2016). Columnar cacti possess rib crests with one trough (intercostal region) on each side of the crest (Figure 1). Rib crests are convex protrusions while troughs (intercostal regions) are concave (Geller \& Nobel, 1984). For each cactus, the rib crests closest to north, south, east and west azimuth were evaluated (Evans et al., 1994a; b; Evans, 1995). Right and left troughs (intercostal regions) of each rib crest were evaluated so twelve surfaces were evaluated for each cactus. For each surface, an 8-centimeter vertical band at 1.75 meters from ground level was evaluated for the percentage of periderm coverage (Evans et al., 1994a; b; Evans, 1995; Evans et al., 2013). The number of cacti within each species evaluated is given in Table 1. Previous research demonstrated that visual and digital methods gave similar results (Evans \& De Bonis, 2015). Periderm coverages were entered into Microsoft Excel files. Photographs of all surfaces provided a permanent record for the study. For analysis, each cactus was placed within a periderm class I, II, III or IV. Classes were broken down by cacti that fell into 0 to 24,25 to 49,50 to 74 , 
and 75 to $100 \%$ periderm on south-facing crests, respectively.

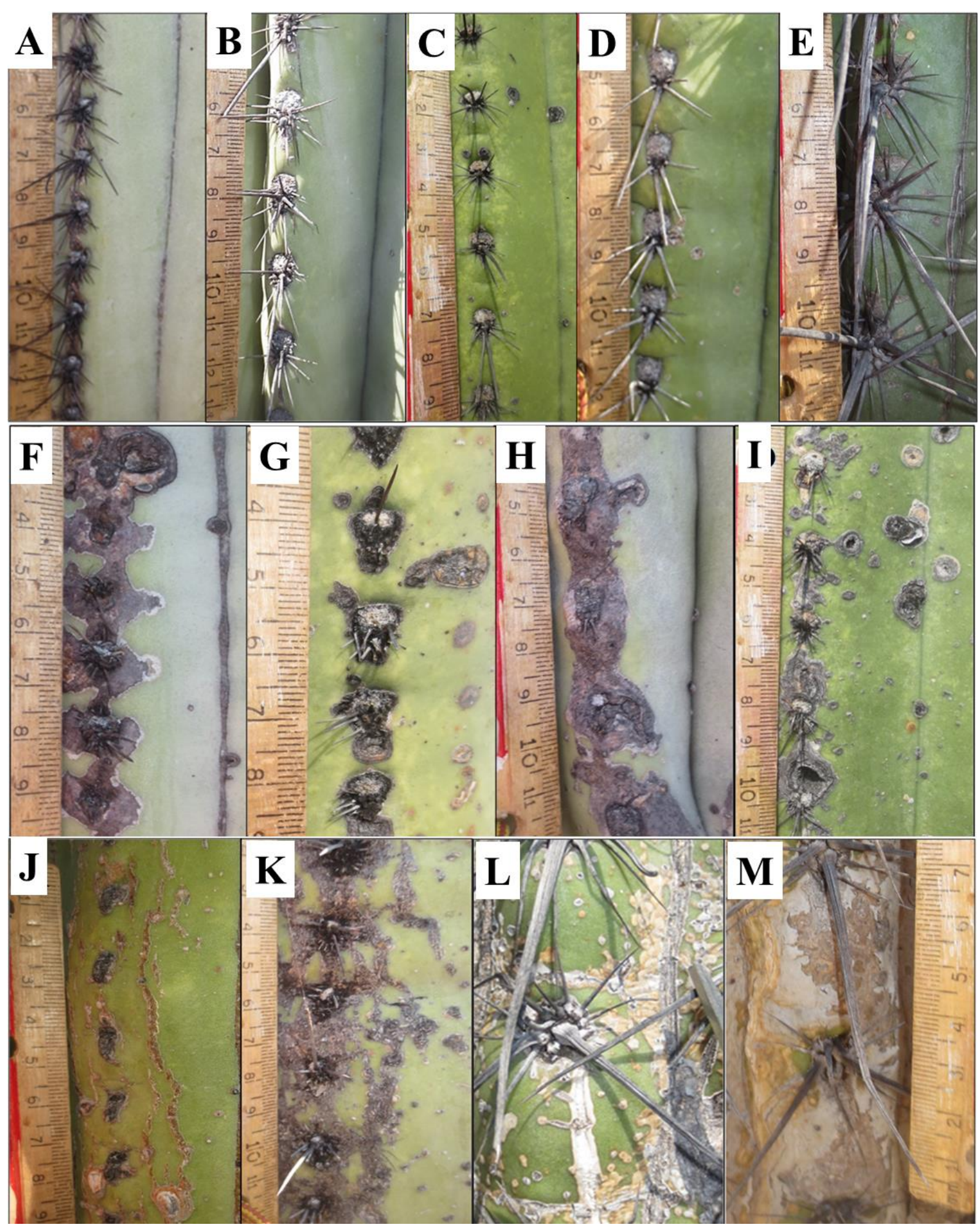

Figure 1. A - E: Images depicting the surface tissues of five columnar cacti species without periderm coverages A: Cephalocereus columna-trajani cactus; B: Cephalocereus macrocephalus; C: Cephalocereus mezcalaensis; D: Cephalocereus tetetzo; E: Pachycereus hollianus. F - I: Images of cactus surface tissues with periderm formation for $C$. columna-trajani, C. macrocephalus, and $C$. mezcalaensis. F: Surface of Cephalocereus columna-trajani cactus with periderm formation that initiated at crests of cactus ribs. Periderm was dark in coloration, smooth in texture, and developed diamond-shaped patches at areoles. G: Surface of Cephalocereus 
macrocephalus cactus with periderm formation that initiated in scattered patches. H: Periderm formation on $C$. macrocephalus localized at crests. I: Surface of Cephalocereus mezcalaensis cactus with periderm formation most prominent at crests. Periderm was grey in coloration and rough in texture. $\mathbf{J}-\mathrm{M}$ : Images of cactus surface tissues with periderm formation for Cephalocereus tetetzo and Pachycereus hollianus. J: Surface of C. tetetzo with periderm in a random fashion except the scarring effect in the trough. Note the orange color of this initial periderm. K: Periderm formation on C. tetetzo in which periderm has covered more the surface. At this stage, the periderm was grey with a rough texture. L: Surface of $P$. hollianus cactus in which periderm coverage initiates at the point where two troughs meet. Note the whitish coloration of the initial periderm. The periderm had a smooth texture. M: Surface of $P$. hollianus with near complete periderm coverage. Note the brown color of the periderm.

Table 1. Numbers of cactus plants analyzed in each class for cacti of Central Mexico

\begin{tabular}{llllll}
\hline Species & Class I & Class II & Class III & Class IV & total \\
\hline Cephalocereus columna-trajani & 6 & 2 & 6 & 22 & 36 \\
Cephalocereus macrocephalus & 44 & 10 & 7 & 21 & 82 \\
Cephalocereus mezcalaensis & 38 & 5 & 9 & 49 & 101 \\
Cephalocereus tetetzo & 23 & 14 & 11 & 11 & 59 \\
Pachycereus hollianus & 32 & 3 & 9 & 30 & 74 \\
\hline
\end{tabular}

Each cactus was placed into one periderm class. Class I, II, III or IV cacti had 0 to 24,25 to 49,50 to 74 , and 75 to $100 \%$ periderm on south-facing crests, respectively.

\subsection{Tissue Analysis}

Tissue samples were obtained from 20 plants of each species. Tissue samples were taken from sample surfaces that were evaluated. A variety of surface samples were taken with a range of periderm coverage from no periderm on the surface to extensive periderm coverage. The range of samples helped to determine the process of periderm formation for each species. Stem tissue samples of $2 \mathrm{~cm}$ height, $1 \mathrm{~cm}$ width and $1 \mathrm{~cm}$ deep were obtained. Tissues were immediately fixed in FAA (Formalin, acetic acid, ethanol) for up to 24 hours (Jensen, 1962). Samples were stored in 70\% ethanol. Tissues were dehydrated in a series of tertiary butanol solutions (Fisher Scientific, Pittsburgh, PA). Samples were embedded in molten paraffin (Paraplast X-tra Tissue Embedding Medium; McCormick Scientific, St. Louis, MO) at $56^{\circ} \mathrm{C}$ and sectioned at $25 \mu \mathrm{m}$ before being placed on microscope slides. Tissues were deparaffinized in xylene, stained with 5\% safranin and mounted permanently in Canada balsam. Photomicrographs of tissues were uploaded onto a computer. ImageJ (imageJ, National Institutes of Health), was used to determine dimensions of cells and tissues.

\subsection{Data Analysis}

Periderm coverages on north-facing and south-facing crests with troughs of Class III and IV were compared. Comparisons of north vs south and crests versus trough coverages were evaluated using least significant difference analysis (Snedecor \& Cochran, 1976).

\section{Results}

Periderm coverages. The cactus plants of this study show a large range of bark coverages. Data of the five cactus species demonstrate that a range of $18 \%$ (Cephalocereus tetetzo) to $61 \%$ (Cephalocereus columna-trajani) of the cacti fell into Class IV in which periderm coverages was more than $75 \%$ (Table 1). These data indicate significant periderm coverages for each species on south-facing surfaces. Cacti of C. columna-trajani aside, all other species studied had more than $40 \%$ of individuals with less than $50 \%$ of periderm coverage (class I and II): C. macrocephalus (65\%), C. mezcalaensis (42\%), C. tetetzo (62\%) and P. hollianus (47\%).

Excluding Class IV cacti of $C$. columna-trajani, periderm percentage coverages on north-facing and south-facing crests of Class III and IV cacti were all statistically significant (Table 2). Comparisons between crest and trough coverages demonstrated all surfaces were statistically significant except south-facing crests/troughs for Class III cacti of $C$. tetetzo. Both sets of differences were expected since south-facing surfaces have more direct sunlight exposures than north-facing surfaces and crest surfaces have more direct sunlight exposures than troughs. Overall, for the cacti of this experiment, more sunlight exposure resulted in more periderm coverage. 
Table 2. Periderm coverages on surfaces of five species of cacti from central Mexico

\begin{tabular}{lllllllll}
\hline & \multicolumn{1}{l}{ South-facing } & \multicolumn{6}{l}{ North-facing } \\
\hline & Crests & \multicolumn{3}{l}{ Troughs } & Crests & \multicolumn{3}{l}{ Troughs } \\
\hline & Right & & Left & & Right & & Left & LSD* \\
\hline Species & Class & $(\%)$ & $(\%)$ & $(\%)$ & $(\%)$ & $(\%)$ & $(\%)$ & \\
\hline Cephalocereus columna-trajani & III & 66.7 & 13.3 & 12.0 & 55.5 & 10.3 & 15.0 & 6.1 \\
& IV & 98.0 & 15.7 & 17.6 & 93.0 & 11.8 & 10.5 & 10.0 \\
C. macrocephalus & III & 62.5 & 19.4 & 12.5 & 21.6 & 2.4 & 4.8 & 5.0 \\
& IV & 96.4 & 57.7 & 59.4 & 65.0 & 41.7 & 41.3 & 4.7 \\
C. mezcalaensis & III & 65.6 & 25.3 & 22.8 & 56.7 & 16.7 & 19.9 & 4.8 \\
& IV & 93.0 & 34.5 & 28.0 & 77.1 & 20.9 & 21.2 & 7.4 \\
C. tetetzo & III & 59.6 & 37.5 & 39.6 & 27.7 & 25.2 & 26.3 & 2.4 \\
& IV & 91.8 & 63.5 & 63.9 & 54.5 & 48.4 & 48.6 & 3.2 \\
Pachycereus hollianus & III & 62.2 & 36.7 & 22.4 & 44.4 & 27.7 & 37.8 & 3.8 \\
& IV & 94.8 & 81.7 & 68.8 & 54.7 & 43.4 & 46.2 & 5.3 \\
\hline
\end{tabular}

*LSD $=$ least significant difference (Snedecor and Cochran, 1976).

Each cactus was placed into one periderm class. Class I, II, III or IV cacti had 0 to 24,25 to 49,50 to 74 , and 75 to $100 \%$ periderm on south-facing crests, respectively.

\subsection{Stem Surface Characteristics without Periderm}

Stem surfaces of $C$. columna-trajani are smooth with a dull green color and pronounced sunlight reflections from surfaces. Areoles have many black spines (Figure 1A). Stems of C. macrocephalus had rounded ribs in young, green plants with whitish spines. Similar to C. columna-trajani, C. macrocephalus had crests that were lighter green than troughs. The rib crests of $C$. macrocephalus were larger than those of $C$. columna-trajani (Figure 1B). Stems of $C$. mezcalaensis had random bright green to yellow patches on surfaces. In regions where two troughs (intercostal regions) joined, troughs had a darker green color compared to other trough areas. Stem surfaces of $C$. mezcalaensis did not reflect sunlight to the extent that C. columna-trajani and C. macrocephalus did (Figure 1C). Stem surfaces of $C$. tetetzo plants had a dull green color with a white tint, indicating the presence of epicuticular waxes in some areas, especially where two troughs met. Crests were very prominent and were brighter green than trough surfaces. Most spines were whitish (Figure 1D). Stems of $P$. hollianus cacti were dark grey-green with many long, thick spines (Hunt, 2006) with a tint indicating sunlight reflection (Figure 1E). The above descriptions are similar to Anderson (2001), Hunt et al. (2006) and Hunt (2013). The patterns of surface characteristics differed among the five species.

\subsection{Stem Surface Characteristics with Periderm}

The surface characteristics of periderm coverages for the five species studied varied. For C. columna-trajani, periderm first formed a diamond-shaped at rib crests (Figure 1F; Table 3). Initially, periderm was gray but eventually became brown to black once all troughs were covered. For $C$. columna-trajani, the periderm texture was initially smooth but became rough as periderm accumulated. Periderm development on troughs occurred after that on crests. For C. macrocephalus, small areas of periderm occurred initially on crests near areoles. When crests were covered with periderm, no spines were present. Periderm covered crests completely before occurring on troughs (Figure 1G, 1H). Initially, periderm was yellow to gray but eventually became black. For surfaces of $C$. mezcalaensis, small areas of periderm developed randomly on surfaces not specifically associated with either crests or troughs (Figure 1I). With higher percentages of periderm coverages on crests, few spines were present. Initially, periderm was yellow but eventually became light grey to dark brown or black with complete periderm coverage. For surfaces of $C$. tetetzo, small areas of periderm developed randomly on surfaces similar to that of C. mezcalaensis (Figure $1 \mathrm{~J}, 1 \mathrm{~K}$ ). Initially, periderm was grey but it eventually became light brown before shifting to dark brown. With extensive periderm coverage, surfaces became flattened and crests became less prominent. Most spines were lost early in periderm formation on crests (Figure $1 \mathrm{~K}$ ). The progress of periderm coverage on $P$. hollianus was unlike that of the other species. Periderm initially formed where two troughs met. From that area, periderm continued to form more on troughs before forming on crests (Figure 1L, $1 \mathrm{M}$ ). When little periderm was present, the periderm was whitish to yellow. When the periderm layer was thicker, the periderm was light grey. Surfaces of $P$. hollianus retained most spines even when most surfaces were covered with periderm. 
Table 3. Anatomical characteristics of five species of cacti from central Mexico

\begin{tabular}{|c|c|c|c|c|c|}
\hline & \multicolumn{2}{|l|}{ Cuticle depth } & \multirow{2}{*}{$\begin{array}{l}\text { Epidermal cell } \\
\text { depth }(\mu \mathrm{m})\end{array}$} & \multicolumn{2}{|l|}{ Hypodermis } \\
\hline & Depth $(\mu \mathrm{m})$ & & & number of las & \\
\hline & No periderm & periderm & No periderm & No periderm & periderm \\
\hline \multicolumn{6}{|l|}{ Species } \\
\hline Cephalocereus columna-trajani & $8 / 2^{\mathrm{a}}$ & not present & $35 / 2$ & $10 / 2$ & $10 / 1$ \\
\hline C. macrocephalus & $5 / 1$ & not present & $42 / 3$ & $10 / 2$ & $11 / 2$ \\
\hline C. mezcalaensis & $4 / 1$ & not present & $39 / 2$ & $7 / 2$ & $6 / 2$ \\
\hline C. tetetzo & $2 / 2$ & not present & $25 / 2$ & $8 / 3$ & $4 / 1$ \\
\hline Pachycereus hollianus & $45 / 3$ & $51 / 3$ & $41 / 2$ & $2 / 1$ & not present \\
\hline
\end{tabular}

a mean and standard deviation, respectively.

\subsection{Stem Anatomy without Periderm}

All five cactus species of the study possessed a cuticle layer, one or two celled epidermis, a multi-cell layered hypodermis (Gibson \&Nobel, 1986; Mauseth, 1988; Loza-Cornejo \& Terrazas, 2003) and chlorenchyma cells (Terrazas \& Arias, 2002). However, the characteristics of these structures differed markedly among species (Figure 2; Table 3). Cuticle thicknesses ranged from 2 to $45 \mu \mathrm{m}$. Epidermal cells were isodiametric (circular) for C. columna-trajani (Figure 2A), columnar (long axis perpendicular with the stem surface) for C. macrocephalus (Figure 2B), rectangular (long axis parallel with the stem surface) for both $C$. mezcalaensis (Figure 2C) and $P$. hollianus (Figure 2E), and multicellular isodiametric which yielded a papillose surface for C. tetetzo (Fig 2D) (Loza-Cornejo \& Terrazas, 2003). Among the species, hypodermal cells were rectangular for C. tetetzo (Figure 2D) and P. hollianus (Figure 2E), cuboidal (squared) for C. mezcalaensis (Figure 2C) and isodiametric for both C. columna-trajani (Figure 2A) and C. macrocephalus (Figure 2B). The numbers of hypodermal cells layers varied from 2.0 to 10 . Cells of the cortical palisade parenchyma had various radially elongated shapes. The five species had distinct dermal characteristics.

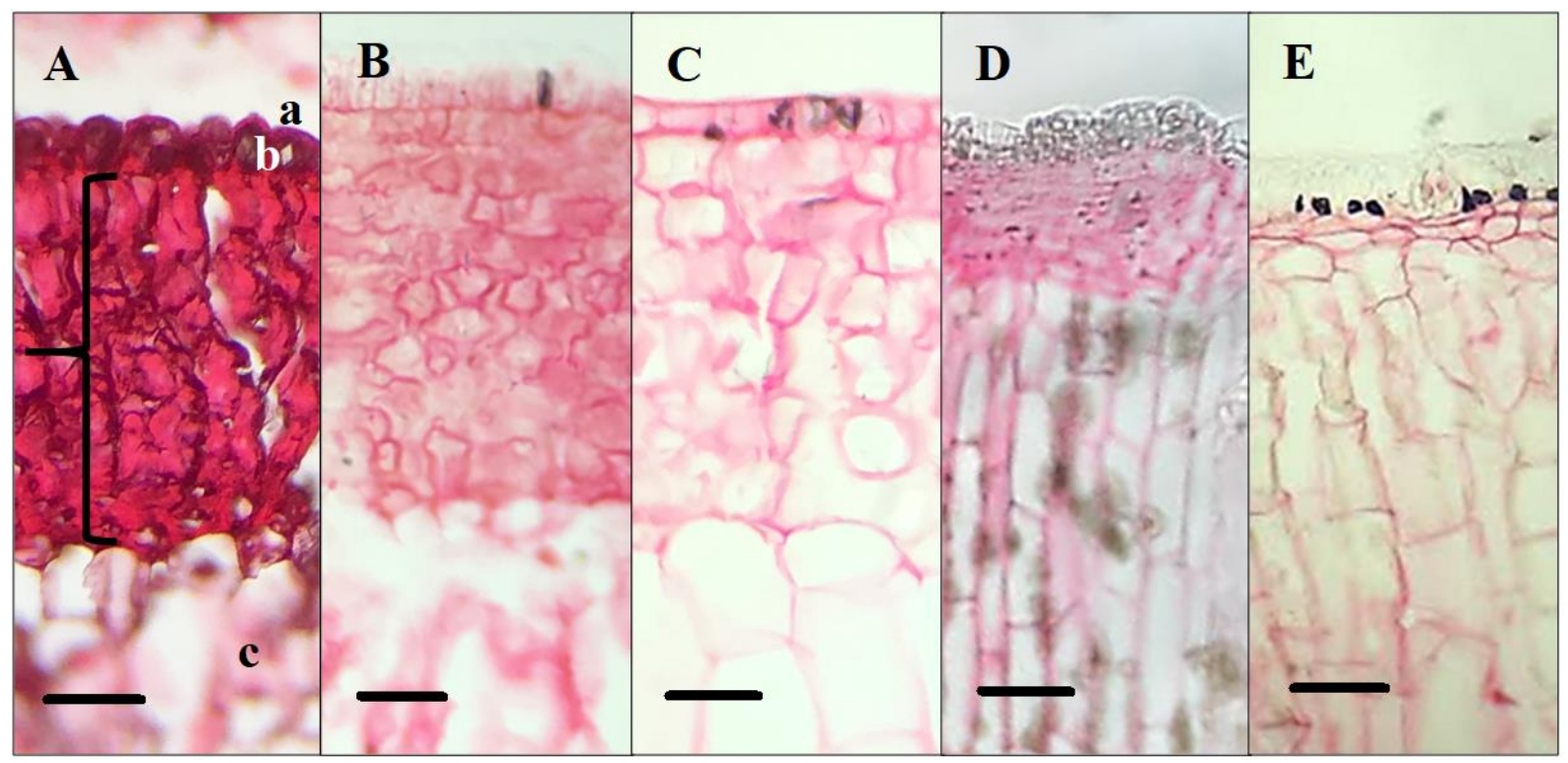

Figure 2. Images tissues of five cacti species without periderm present

All cacti had an outer surface cuticle (a). Internally, cacti had a unicellular epidermis layer (b), a multicellular hypodermal layer ( $\{$ ), and chloroenchyma cells (c). A: Cephalocereus columna-trajani had isodiametric-shaped epidermal cells, with a multicellular hypodermis layer of cuboidal / rectangular-shaped cells, and oval-shaped chloroenchyma cells. Scale $100 \mu \mathrm{m}$. B: Cephalocereus macrocephalus had columnar-shaped epidermal cells, a multicellular hypodermis layer of isodiametric-shaped cells, and columnar-shaped chloroenchyma cells. Scale 80 $\mu \mathrm{m}$. C: Cephalocereus mezcalaensis had rectangular-shaped epidermal cells, a multicellular hypodermis with isodiametric/cuboidal-shaped cells, and columnar-shaped chloroenchyma cells. Scale $90 \mu \mathrm{m}$. D: Cephalocereus tetetzo had a multicellular epidermis, a multicellular hypodermis layer with isodiametric and rectangular-shaped 
cells, and columnar-shaped chloroenchyma cells. Scale $100 \mu \mathrm{m}$. E: Pachycereus hollianus had a thick cuticle with isodiametric-shaped epidermal cells. The hypodermis consisted of one or two cell layers, with rectangular-shaped cells. The chloroenchyma cells were columnar-shaped. Scale $80 \mu \mathrm{m}$.

\subsection{Stem Anatomy with Periderm}

The anatomical characteristics during phellogen formation and periderm development differed among the species. For many species of cacti, the periderm, phellem cells are produced by only periclinal cell divisions of the epidermal cells that becomes the phellogen (periderm cambium; Gibson \& Nobel, 1986; Evans \& Cooney, 2015). This process occurred for most cactus species involved in this study except $C$. macrocephalus. Epidermal cells in stems of C. macrocephalus had one set of anticlinal cell divisions prior to the periclinal cell divisions to produce the phellogen. For all species, the underlying tissues remained intact during the initial stages of periderm formation (Table 3). The phellogen continued to create addition periderm cells so that older periderm cells are pushed farther from the surface. In most cases the periderm was stratified, exhibiting strata of thin-walled phellem cells that alternated with strata of thick-walled phellem cells.

Periderm development for P. hollianus was different than for the other species of this study (Figure 3). The phellogen was formed by the epidermis and produced phellem cells (Figure 3B). With more cell divisions of the phellogen, the hypodermal cells became indistinguishable from other tissues (Figure 3C, 3D). Abnormal cells divisions occurred in the chloroenchyma (Figure 3D). Throughout the process the cuticle remained intact, possibly because the phellem did not exfoliate. Phellem exfoliation occurred with the other four species.

The periderm formation processes for both $C$. mezcalaensis and $C$. tetetzo differed from the process described above for $P$. hollianus. The thick cell walls of the hypodermis were not present once the phellogen was produced (Figure 3E, 3F). The phellogen produced a regularly layered periderm, prior to collapse of phellem cells (Figure 3G). For both C. mezcalaensis and C. tetetzo, cuticles were not present after the phellem was formed (Figure 3G, $3 \mathrm{H}$ and $3 \mathrm{I})$. For $C$. tetetzo, chlorenchyma cells changed shape. Additionally, the phellem exfoliated.

Periderm formation for $C$. macrocephalus differed from the other species of this study, since epidermal cells underwent an anticlinal cell division prior to the periclinal cell divisions that eventually produced the phellogen (Figure 3K). During the initial cell divisions of the epidermis, the cuticle fragmented and was not present after the phellogen formed (Figure 3K). Unlike the other species, hypodermal cells did not change in size or depth during the early stages of phellem formation (Figures 3J, 3K and 3L). After phellem formation was underway, hypodermal cells lost their form. Eventually, the phellem was stratified with strata of thin-walled phellem cells alternating with strata of thick-walled phellem cells (Figure 3M). Changes in tissues for C. columna-trajani involved the production of a very thick phellem. The phellogen produced cells in distinct columns (Figure $3 \mathrm{~N}$ ). The phellem became stratified with strata of thin-walled phellem cells alternating with strata of thick-walled phellem cells (Figure 3O, 3P). During the process, hypodermal cells enlarged with more intercellular spaces. Chlorenchyma cells changed in size and shape (Figure 3P). 

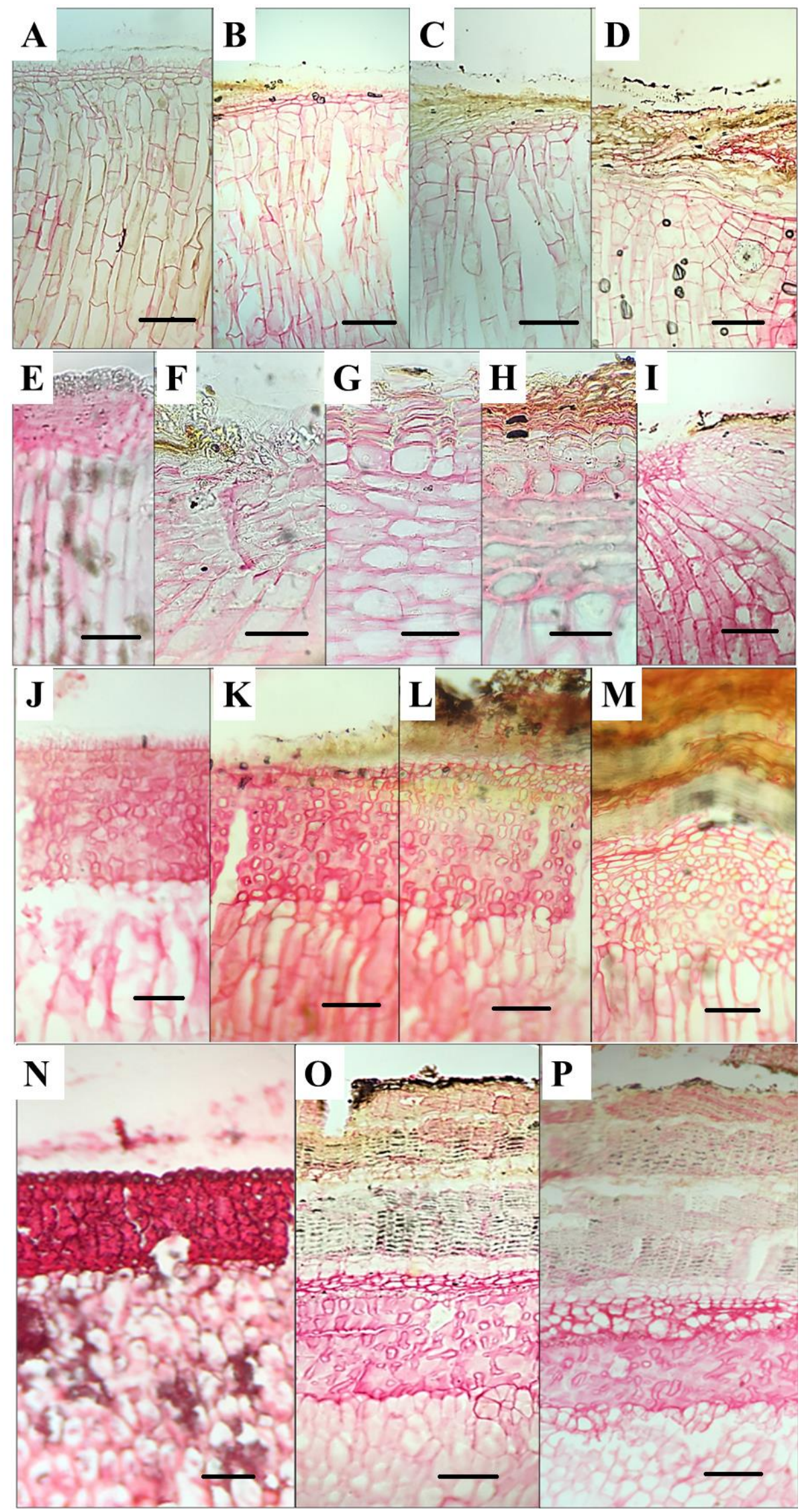

Figure 3. A - D: Images of the progression of periderm formation for Pachycereus hollianus 
A: Microscope image of healthy tissues before the phellogen develops. B: With periclinal cell divisions of the phellogen the hypodermis is intact. The cuticle layer is intact and is not deformed. C: The phellogen has continued to divide to produce a phellem of relatively thin cells. The hypodermis layer has lost structure. D: The cuticle is intact even with an extensive periderm. The hypodermis layer is not distinguishable. The chloroenchyma cells changed size and shape. All scales $100 \mu \mathrm{m}$. E - I: Images of the progression of periderm formation for Cephalocereus tetetzo. E: Healthy tissues without periderm. Scale $100 \mu \mathrm{m}$. F: Epidermal cells proliferate to form a phellogen but not in an organized manner. As the phellem develops hypodermal cells are crushed and the chloroenchyma is disorganized. Scale $120 \mu \mathrm{m}$. G: Organized periclinal cell divisions have produced layers of have started to produce a periderm. The cuticle is disorganized. The chloroenchyma cells has changed markedly. Scale $100 \mu \mathrm{m}$. H: The outermost phellem cells are exfoliating and many other phellem cells have collapsed. Scale $100 \mu \mathrm{m}$. I: The periderm is markedly compressed cells. The chloroenchyma cells have remained disorganized. Scale $90 \mu \mathrm{m}$. J - M: Images of the progression of periderm formation for Cephalocereus macrocephalus. J: Healthy tissues. K: The columnar-shaped epidermal cells undergo a periclinal cell division before the phellogen forms. As the phellem develops, the hypodermis remains intact until there is a very thick periderm. There are more intercellular spaces among hypodermal cells. L: Darkly stained periderm is present. The cuticle is not present. The hypodermal cells continue enlarge but the layer remains intact. M: The periderm was stratified with strata of thin-walled phellem cells alternating with strata of thick-walled phellem cells. Hypodermal cells have lost their thick cell walls with some crushed cells. The chloroenchyma cells have changed size and shape. All scales $100 \mu \mathrm{m}$. N - P: Images of the progression of periderm formation for Cephalocereus columna-trajani. N: Healthy tissues. O: A periderm has developed. The periderm was stratified with strata of thin-walled phellem cells alternating with strata of thick-walled phellem cells. The hypodermal cells that enlarged and there are more intercellular spaces between hypodermal cells. P: Extensive stratified periderm. The hypodermal cells have enlarged further and have more intercellular spaces. Chlorenchyma cells have changed in size and shape. All scales $100 \mu \mathrm{m}$.

\section{Discussion}

Cactus species show a wide variety of dermal anatomies from a wide range of regions and local environments. Mauseth (1996) demonstrated that 8 of 21 species surveyed within nine genera had more than one epidermal cell layer. Mauseth et al. (2008) showed that numbers of hypodermal layers and thicknesses of the hypodermal layers ranged from 2 to 6 layers and 34 to $858 \mu \mathrm{m}$, respectively, for 26 species of 12 genera of cactus plants. Loza-Cornejo \& Terrazas (2003) demonstrated that cuticle depths, epidermis widths, epidermis lengths, and hypodermal depths varied from 1 to 225,13 to 67,11 to 77 , and 18 to $626 \mu \mathrm{m}$, respectively, for 70 species of 21 genera. Evans and Cooney (2015) demonstrated that cuticle depths, epidermis depths, and hypodermal depths varied from 3.9 to $73.9,8.7$ to 49.7 , and 37.8 to $661 \mu \mathrm{m}$, respectively. The above mentioned plants of the three studies above came from a wide variety of microenvironments of the Americas. The five species of the current study are within these large ranges. Epidermal cells with thin cell walls, areas of multiseriate epidermal cells, few hypodermal layers and hypodermal cells with medium thickness walls are thought to be relictual characteristics for cactus species (Mauseth et al., 2008).

The data of this study show higher periderm coverages on south-facing surfaces than on north-facing surfaces. A previous study with $C$. mezcalensis and $C$. tetetzo at the location of this study (Evans, 2005) demonstrated that south-facing surfaces had two times more periderm coverages than north-facing surfaces. The results of the current study showed similar south to north directional ratios. A 2:1 south to north ratio of periderm coverages coincides with a 2:1 calculated ratio of direct sunlight exposures on south to north-facing surfaces on an upright pole at $18^{\circ} \mathrm{N}$ latitude (Geller, 1984). Moreover, enhanced levels of controlled exposures to UV-B radiation produced identical epidermal wax accumulation that occurred in nature during sunlight-induced periderm formation (Evans et al., 2001). These results reinforce the idea that periderm formation on these species of this study is initiated by sunlight. So, the periderm of this study is sun-light induced.

Most species of cacti previously studied (Evans et al., 1994a; b) in North and South America had periderm coverages on crests initially and only later had coverages on troughs similar to Scenario \#3 in Table 3. In contrast to this sequence, stems of $P$. hollianus show initial periderm formation at junctions between adjacent troughs. Crests show periderm coverages after troughs. The reasons for varying visible manifestations among species is unknown at present. Moreover, many tall-long-lived columnar cacti species show a range of periderm colorations. For example, the periderm of Oreocereus celsianus from northern Argentina has a whitish color beneath an abundance of spines (Evans et al., 1994b). For many columnar species, the usual brown color of the periderm becomes completely black over time (Evans et al., 1994a; b). 
Periderm formation in cacti is caused by cell divisions of the epidermis only. Gibson \& Nobel (1986) indicated that the periderm is formed only by periclinal cell divisions of epidermal cells. When the epidermis starts cell divisions, it can be referred to as a phellogen, analogous to the cork cambium of woody plants. Cork cells (phellem) derived from the phellogen form stacks of flat cells (Gibson \& Nobel, 1986). Epidermal cells may be stimulated to start cell divisions to produce the phellogen after an accumulation of epicuticular waxes on surfaces (Evans et al., 1994a; 2001).

As stated previously, Gibson \& Nobel (1986) demonstrated that the phellogen (bark cambium) is created by epidermal cells in Ferocactus robustrus by periclinal cell divisions only. The phellogen is also produced by periclinal cell divisions only in Carnegiea gigantea (Evans et al., 1994a). Recent evidence indicated that some cactus species have anticlinal cell divisions of epidermal cells to create the phellogen before the large number of periclinal cell divisions to generate a multilayered phellem (Evans \& Cooney, 2015). For stems of $C$. macrocephalus, epidermal cells had one set of anticlinal cell divisions prior to the periclinal cell divisions to produce the phellogen. These anticlinal cell divisions reduce the widths of epidermal cells. There may be a variety of processes to generate a phellogen and phellem cells as indicated by the scenarios in Table 4.

Table 4. Scenarios of periderm formation for species of columnar cacti from Mexico and South America

\begin{tabular}{ll}
\hline Scenario characteristics & Species \\
\hline \#1 Cuticle remains intact, hypodermis is not present & $\begin{array}{l}\text { Pachycereus hollianus, Armatocereus mataranus, } \\
\text { Echinopsis iquiquensis, A. arduus } \\
\text { Cephalocereus macrocephalus }\end{array}$ \\
\#2 Cuticle not present, hypodermis & \\
deformed, chloroenchyma unchanged & Cephalocereus mezcalaensis, C. tetetzo, Cleistocactus \\
\#3 Cuticle not present, both hypodermis & tenuiserpens, Echinopsis atacamensis, E. pachanoi, E. \\
and chloroenchyma deformed & atacamensis, Neoraimondia arequipensis \\
& Cephalocereus columna-trajani, \\
\#4 Cuticle not present, hypodermis & Weberbauerocereus weberbauri \\
unchanged, chloroenchyma cells deformed & Echinopsis chiloensis ssp. skottsbergii, \\
\#5 Cuticle not present, hypodermis cells & E. coquimbana, E. angelesiae \\
crushed, chloroenchyma cells deformed & Echinopsis chiloensis ssp. chiloensis \\
\#6 Cuticle not present, hypodermis depth & Cereus aethiops \\
increased, chloroenchyma
\end{tabular}

cells change in size/shape

\#7 Cuticle remains intact, hypodermis unchanged, Echinopsis terschekii

chloroenchyma crushed, periderm formed above

and below hypodermis

\#8 Cuticle not present, hypodermal cells enlarge, Eulychnia acida

chloroenchyma cells change size/shape.

Special note: All species from South America and Cephalocereus macrocephalus had anticlinal cell divisions prior to periclinal divisions to produce the periderm. The other four species from Mexico did not have anticlinal cell divisions prior to periclinal divisions to produce the periderm.

There are several causes of periderm formation for cacti. Most species of tall, long-lived cactus species produce wound periderm tissues near ground level due to wounds caused by rodents (Orr et al., 2015). Most species of Opuntia and Cylindropuntia species display periderm tissues as a response to compressive and tensile stresses at cladode to cladode junctions (Nobel \& Meyer 1991; Kahn-Jetter et al., 2000). Periderm tissues are normal at junctions of heavy branches of tall, long-lived columnar cactus species that experience compressive forces (Gibson \& Nobel, 1986). Periderm tissues also occur as wound healing responses caused by birds and other invaders (https://www.pinterest.com/pin/182958803592229667). Although, a periderm can be produced under the above circumstances, the periderm produced by the cacti of this study show a strong directionality and thus are a response to sunlight exposures as in many other publications (Evans et al., 1994a, b; Evans, 2005; Evans \& Cooney, 2015).

Sunlight-induced phellem formation altered internal tissues in many ways. The five species of the current study were placed into four scenarios (Table 4) while data from Evans \& Cooney (2015) provided an additional four scenarios for internal changes during periderm formation. Gibson \& Nobel (1986) suggested that when periderm forms on cacti, the thick walls of the hypodermis become thinner and ultimately become indistinguishable from chlorenchyma cells. With the small number of anatomical samples that have been processed, cause and effect 
relationships between phellem production and changes to internal tissues are not warranted. More diverse responses may occur. Data in Table 4 show that cacti in two scenarios (\#1 and \#7) do not lose their cuticles. Of the scenarios that lose their cuticles, hypodermal cells become deformed (\#2, \#3, \#5) or change size and shape (\#6 and \#8). Hypodermal cells remained unchanged for two cactus species in scenario \#4. Changes in chlorenchyma cells are not related to changes in hypodermal cells. Previous research with periderm coverages on columnar cactus species was done with plants at a large variety of locations from $32^{\circ} \mathrm{N}$ to $32^{\circ} \mathrm{S}$ and many locations including near the Equator (Evans \& Macri, 2008). Although some similarities of periderm coverages determined herein are similar to cacti at other locations (Evans \& Fehling, 1994; Evans \& Cooney, 2015), data from this study show that surface responses and internal manifestations may differ markedly among the five species. Overall, there are no uniform surface or internal cellular responses during periderm formation among cactus species at the various locations where they are found as well as at the one location of this study.

Periderm coverages inhibit gas exchange so that eventually internal tissues become anoxic (Lajtha \& Kolberg, 1992; Evans et al., 1994a; Lajtha et al., 1997) and secondary pathogens may enter (Steenbergh \& Lowe, 1977), leading to morbidity and mortality of saguaro cacti (Evans et al., 2013; Evans \& De Bonis, 2015). The fact that between 18 and $61 \%$ of the populations of this study had more than $75 \%$ periderm coverage on south-facing surfaces suggests some the cacti of this study may in a state of morbidity. To emphasize this morbidity issue, for a large population of saguaro cacti, there was a $100 \%$ probably of cactus death within an eight year period after north-facing right troughs had more than $85 \%$ periderm coverages (Evans et al., 2019).

\section{Conclusion}

More than twenty-three species of tall, long-lived columnar cacti from a large variety of locations within the Americas show sunlight-induced periderm development on their stems. Periderm coverages lead to cactus morbidity and mortality. The current study determined periderm coverage patterns and anatomical characteristics of periderm formation of five cactus species located at a single site in the Tehuacán Valley of Puebla, Mexico. Periderm coverages and patterns of periderm on cactus surface varied among the species. On surfaces, some species had periderm form at crests initially, while one species had initial periderm form where troughs join. All species had the same internal tissues prior to periderm formation. Each species showed unique periderm coverages on surfaces. Moreover, the histological changes that resulted from periderm formation were specific for each species and no pair of species showed the same responses to periderm formation.

\section{Author Contributions}

LSE initiated the research, provided research funds, designed the approaches used, evaluated periderm coverages on surfaces, processed most of the tissues for histology, sectioned all the tissues, evaluated tissue samples, organized the manuscript, wrote the manuscript and edited it. PD: helped identify cacti to be sampled with location authorities in the field, processed some of the tissues for histology, evaluated all the tissue samples, helped to organize the photographs for the manuscript.

\section{Acknowledgements}

The author is indebted to the Catherine and Robert Fenton Endowed Chair to L. S. Evans for financial support for this research. The authors appreciate the editing of the manuscript by Lilliana McHale.

\section{References}

Angyalossy, V., Pace, M. R., Evert, R. F., Marcati, C. R., Oskolski, A. A., Terrazas, T., ... Baas, P. (2016). IAWA List of Microscopic Bark Features. IAWA Journal, 37, 517-615. https://doi.org/10.1163/22941932-20160151

Altesor, A., \& Ezcurra, E. (2003). Functional morphology and evolution of stem succulence in cacti. J Arid Environ, 53, 557-567. https://doi.org/10.1006/jare.2002.1059

Anderson, E. (2001). The Cactus Family. Timber Press. Portland, OR.

Darling, M. S. (1989). Epidermis and hypodermis of the saguaro cactus (Cereusgiganteus): anatomy and spectral properties. Am. J. Bot., 76, 1698-1706. https://doi.org/10.1002/j.1537-2197.1989.tb15155.x

Dávila, P., Valiente-Banuet, A., Villaseñor, J., Casas, A., \& Lira, R. (2002). In Biological diversity in the Tehuacán-Cuicatlán Valley, Mexico. Biodiversity and conservation, 11, 421-442. https://doi.org/10.1023/A:1014888822920

Evans, L. S. (2005). Stem surface injuries of Neobauxbaumia tetetzo and Neobauxbaumia mescalaensis of the Tehuacan Valley of central Mexico. J. Torrey Bot. Soc., 132, 33-37. https://doi.org/10.3159/1095-5674(2005)132[33:SSIONT]2.0.CO;2 
Evans, L. S., \& De Bonis, M. (2015). Predicting morbidity and mortality of saguaro cacti (Carnegiea gigantea). J. Torrey Bot. Soc. 142, 231-239. https://doi.org/10.3159/TORREY-D-14-00084.1

Evans, L. S., Boothe, P., \& Baez, A. (2013). Predicting morbidity and mortality for a saguaro cactus (Carnegiea gigantea) population. J. Torrey Bot. Soc., 140, 247-255. https://doi.org/10.3159/TORREY-D-12-00079.1

Evans, L. S., Cantarella, V., Stolte, K., \& Thompson, K. H. (1994a). Epidermal browning of saguaro cacti (Carnegiea gigantea): Surface and internal characteristics associated with browning. Environ. Exper. Bot., 34, 9-17. https://doi.org/10.1016/0098-8472(94)90003-5

Evans, L. S., \& Fehling, B. J., (1994). Surficial injuries of several long-lived columnar cacti of the Sonoran Desert. Environ. Exp. Bot., 34, 19-23. https://doi.org/10.1016/0098-8472(94)90004-3

Evans, L. S., \& Johnson, C. (2018). Machine Learning Programs Predict Saguaro Cactus Death. J Comput Sci Syst Biol, 11, 6.

Evans, L. S., McKenna, C., Ginocchio, R., Montenegro, G., \& Keisling, R. (1994b). Surficial injuries of several cacti of South America. Environ. Exper. Bot., 34, 285-292. https://doi.org/10.1016/0098-8472(94)90049-3

Evans, L. S., Sullivan, J. H., \& Lim, M. (2001). Initial effects of UV-B radiation on stem surfaces of Stenocereus thurberi (Organ Pipe cacti). Environ. Exper. Bot., 46, 181-187. https://doi.org/10.1016/S0098-8472(01)00094-6

Evans, L. S., \& Macri, A. (2008). Stem surface injuries of several species of columnar cacti of Ecuador. J. Torrey Bot. Soc., 135, 475-482. https://doi.org/10.3159/07-RA-020R1.1

Evans, L. S., \& Cooney, M. (2015). Sunlight-induced periderm formation in long-lived South American columnar cacti. Flora, 217, 33-40. https://doi.org/10.1016/j.flora.2015.09.012

Evans, L. S., Shackley, A., \& Printy, O. (2020). Machine learning algorithms predict bark coverages on saguaro cacti (Carnegiea gigantea). Flora, 263, 151527. https://doi.org/10.1016/j.flora.2019.151527

Garcia, J., Scremin-Dias, E., \& Soffiatti, P. (2012). Stem and root anatomy of two Species of Echinopsis (Trichocereae: Cactaceae). Rev. Mex. Biodiv., 83, 202-221. https://doi.org/10.7550/rmb.28124

Geller, G., \& Nobel, P. (1984). Cactus ribs: influence of PAR inception and CO2 uptake. Photosynthetica, 18, 482-494.

Gibson, A. C., \& Horak, K. (1978). Systematic anatomy and phylogeny of Mexican columnar cacti. Ann. MO. Bot. Garden, 65, 999-1057. https://doi.org/10.2307/2398781

Gibson, A., \& Nobel, P. S. (1986). The cactus primer. Harvard University Press, Cambridge, MA. https://doi.org/10.4159/harvard.9780674281714

Ginocchio, R., \& Montenegro, G. (2000). Abnormal bark formation in Echinopsis chilensis, a long lived tall columnar cacti of Central Chile. Gayana Bot., 57, 141-147.

Hunt, D. (2013). The New Cactus Lexicon Illustrations. dh Books. Milborne Port, UK.

Hunt, D., Taylor, N., \& Charles, G. (2006). The New Cactus Lexicon. Two volumes. dh Books. Milborne Port, UK.

Jensen, W. (1962). Botanical Histochemistry. W.H. Freeman and Co. University of California, Berkeley.

Kahn-Jetter, Z., Evans, L. S., Grazan, J., \& Frenz, C. (2000). Compressive/tensile stresses and lignified cells as resistance components in joints between cladodes of Opuntia laevis (Cactaceae). Int. J. Plant Sci., 161, 447-462. https://doi.org/10.1086/314259

Lajtha, K., \& Kolberg, K. (1992). Ecophysiological and toxic element studies of the saguaro cactus in Saguaro National Monument. In C. P. Stone \& E. S. Bellantoni (Eds.), Proceedings of the Symposium on Research in Saguaro National Monument (pp. 47-55). Southwest Parks and Monuments Association, Globe, Arizona.

Lajtha, K., Kolberg, K., \& Getz, J. (1997). Ecophysiology of the saguaro cactus (Carnegiea gigantea) in the Saguaro National Monument: relationship to symptoms of decline. Journal of Arid Environments, 36, 579-590. https://doi.org/10.1006/jare.1996.0240

Loza-Cornejo, S., \& Terrazas, T. (2003). Epidermal and hypodermal characteristics of North American Cactoideae (Cactaceae). J. Plant Res., 116, 27-35. https://doi.org/10.1007/s10265-002-0066-2

Mauseth, J. (1988). Plant Anatomy. The Blackburn Press. Caldwell, NJ.

Mauseth, J. D. (1996). Comparative anatomy of tribes Cereeae and Browningieae (Cactaceae). Bradleya, 14, 
66-81. https://doi.org/10.25223/brad.n14.1996.a9

Mauseth, J., \& Keisling, R. (1997). Comparative anatomy of Neoraimondia roseiflora and Neocardenasia herzogiana (Cactaceae). Haseltonia, 5, 37-50.

Mauseth, J. D., Terrazas, T., \& Loza-Cornejo, S. (2008). Anatomy of relictual members of subfamily Cactoidaea, IOS Group 1a (Cactaceae). Bradleya, 16, 31-43. https://doi.org/10.25223/brad.n16.1998.a5

Nobel, P., \& Meyer, R. (1991). Biomechanics of cladodes and cladode-cladode junctions for Opuntia ficus-indica (Cactaceae). Am J. Bot., 78, 1252-1259. https://doi.org/10.1002/j.1537-2197.1991.tb11418.x

Rizzardini, G. M. (1984). Atlas de Anatomia de Especies Vegetales Autoctonas de laZona Central. Ediciones, Universidad Catolica de Chile, Santiago, Chile.

Orr, T., Newsome, S., \& Wolf, B. (2015). Cacti supply limited nutrients to a desert rodent community. Oecologia. https://doi.org/10.1007/s00442-015-3304-8

Smith, C. (1965). Flora Tehuacán Valley. Fieldiana Botany, 31, 107-143.

Snedecor, G., \& Cochran, W. (1976). Statistical Methods. The Iowa State University Press. Ames, IA.

Soffiatti, P., \& Angyalossy, V. (2007). Anatomy of Brazilian Cereeae (subfamilyCactoideae, Cactaceae): Arrojadoa Britton and Rose, Stephanocereus A. Bergerand Brasilicereus Backberg. Acta Bot. Bars., 21, 813-822. https://doi.org/10.1590/S0102-33062007000400006

Steenbergh, W., \& Lowe, C. (1977). Ecology of the Saguaro II. Scientific Monograph Series 8. National Park Service, Washington, DC. p. 242.

Terrazas, T., \& Arias, S. (2002). Comparative stem anatomy in the subfamily Cactoidae. Bot Rev., 68, 444-473. https://doi.org/10.1663/0006-8101(2002)068[0444:CSAITS]2.0.CO;2

Valiente-Banuet, A., \& Ezcurra, E. (1991). Shade as a cause of the association between the cactus Neobuxbaumia tetetzo and the nurse plant Mimosa luisana in the Tehuacan Valley, Mexico. J. Ecology, 79, 961-971. https://doi.org/10.2307/2261091

UNESCO. Tehuacán-Cuicatlán Valley: Origin habitat of Mesoamerica. United Nations Educational, Scientific and Cultural Organization. Retrieved from http://whc.unesco.org/en/list/1534/

http://www.sanjuanraya.com. San Juan Raya Centro Ecoturistico. San Juan Raya homepage.

https://www.pinterest.com/pin/182958803592229667/

\section{Copyrights}

Copyright for this article is retained by the author(s), with first publication rights granted to the journal.

This is an open-access article distributed under the terms and conditions of the Creative Commons Attribution license (http://creativecommons.org/licenses/by/4.0/). 